Page 119-136. ISBN: 978-602-6 988-75-1

Web Jurnal Online: jurnal.unmuhjember.ac.id

By: Rinikso Kartono

The Role Of Peer Support Group To Restore The Ability

Of Resilience Of People With Hiv / Aids (Plwha)

\title{
THE ROLE OF PEER SUPPORT GROUP TO RESTORE THE ABILITY OF RESILIENCE OF PEOPLE WITH HIV / AIDS (PLWHA)
}

\author{
Rinikso Kartono \\ (rinikso@gmail.com) \\ University of Muhammadiyah Malang
}

\begin{abstract}
HIV/ AIDS that infects a person will not only reduce body immune system, but also reduce one's resilience ability. As a result, PLWHA become powerless in dealing with the disease and their social lives. The presence of peer support groups is very helpful to restore the resilience of PLHIV in dealing with diseases and their effects. This study aims to describe; 1) The role of peer support groups to restore the resilience of PLWHA.2) The Impact of Social Support on Restore Resilience Of PLHAs. This research used qualitative approach and data collection technique conducted by interview and observation and Focus Group Discussion (FGD). Meanwhile, the subjects of this study are PLWHA, and member of Peer Support Groups.This study found that: (1) The role of peer support groups to restore the resilience of PLWHA are; 1) Provider temporary shelter; b) Companion and counselor; c) Educator and trainer; d) Advocate. (2) The roles of peer support group to improve the resilience of PLWHA consists of; a) PLWHA can adapt to HIV / AIDS which infects it, optimistic, hopefull, without experiencing stress; b) improvement in the quality of PLWHA's health; c) Increasing social role of PLWHA; d) PLWHA becomes more pro-social and religious
\end{abstract}

Keywords. Support, Resilience, PLWHA, HIV/AIDS 
Page 119-136. ISBN: 978-602-6 988-75-1

Web Jurnal Online: jurnal.unmuhjember.ac.id By: Rinikso Kartono

The Role Of Peer Support Group To Restore The Ability Of Resilience Of People With Hiv / Aids (Plwha)

\section{INTRODUCTION}

The growth rate of HIV/ AIDS in Indonesia continues to grow rapidly and is listed as the fastest in Asia. Based on data from the Ministry of Health of the Republic of Indonesia [1] the cumulative number from 1 January 1987 to 31 December 2016 was 319,048 consisting of 232,323 people infected with HIV and 86,725 people who were infected AIDS. The province with the most rapid development of HIV and AIDS is East Java Province. For AIDS figures in 2016 East Java ranks first and surpasses DKI Jakarta, Papua and West Java, namely; East Java $(14,499)$, Papua $(13,335)$, DKI Jakarta $(8,105)$, Bali $(5,934)$, Central Java $(5,049)$, West Java $(4,919)$, Likewise in East Java HIV cases ranked second after Jakarta namely Jakarta (40,500), East Java (26,052), Papua $(21,474)$, West Java $(18,727)$ and Central Java (13,547). Whereas in the previous three years East Java was third in HIV and fourth in AIDS.

Becoming a PLWHAs is a process of alternation, namely the process by which it experiences life changes. Their lives can get worse and even die faster. Evidence of the deterioration of PLWHAs can be seen from the results of $\mathrm{Yu}$ and colleagues' research [2] that focus on resilience among people living with HIV. Yu and colleagues found that among HIV positive adults in China, resilience was negatively associated with depression, anxiety, and stress. whereas Lyons and colleagues [3] found that having been diagnosed with anxiety or mood disorder was associated with decreased resilience among gay men living with HIV in Australia.

De Santis [4]suggests that empowerment is important. Kartono's [5] research found evidence that someone infected with HIV/ AIDS will experience four aspects of powerlessness. First, physical powerlessness is characterized by reduced body strength, wasting AIDS or weight loss such as fat loss (lean body mass) and muscle mass, and paralysis. Second, psychological powerlessness such as fear, stress, depression, memory loss or dementia to suicidal desires. Third, economic powerlessness is a continuation of physical, psychological, social and political powerlessness. Economic injustice starts from the loss of livelihoods and income, to a high cost of living for treatment. Usually economic powerlessness exacerbates the condition of people with HIV/ AIDS. Fourth, social and political powerlessness such as getting stigmatized, discriminatory treatment, exclusion and violence.

Another fact shows the opposite that PLWHA can successfully carry out resilience such as being able to survive and adjust to living with HIV/ AIDS and their environment if they get social support from people who have caring. Social support is an important aspect to increase resilience of people with HIV. Acoording Chada, at all, [6] there is a strong need for social support for those living with HIV / AIDS, not only from family members, but other services provided by relevant stakeholders and communities. Sustainable social support that can increase the resilience of individuals and families to face current illnesses. Become more resilient that can reduce vulnerable PLWHA to continue to be trapped in various forms of problems that might adversely affect their livelihoods. 
Page 119-136. ISBN: 978-602-6 988-75-1

Web Jurnal Online: jurnal.unmuhjember.ac.id By: Rinikso Kartono

The Role Of Peer Support Group To Restore The Ability Of Resilience Of People With Hiv / Aids (Plwha)

People living with HIV / AIDS (PLWHA) are people who need social support in the process of treatment, care and restore resilience to be able to live naturally despite being infected with HIV / AIDS. If PLWHA don't get social support, they can experience health problems, lack of care, for loss of hope, and powerlessness. The results of quantitative studies conducted by Alaiya Choiril Mufidah, [7] prove that there is a positive relationship between social support and resilience. Fang and colleagues [8] found social support (interpersonal) to become important elements of resilience among older adults living with HIV.

Emlet, Tozay, and Raveis [9], are identified as relational living (formal and informal support) and generativity as important elements of resilience. Meanwhile, qualitative research conducted by Kartono [10] on social support based on peer support groups in overcoming the powerlessness of PLWHA concluded that PSG was a group that grew from and by PLWHA who provided social support by providing PLWHA shelter to create a sense of security and comfort, providing information on education, motivation, can improve the empowerment of PLWHA. In Cluver et al. [11] study with 703 children and adolescents (425 AIDS-orphaned and 278 nonorphaned) in South Africa, suggesting that support from peers, carers, family mentors, and other people from the community may reduce the deleterious effects of a range of traumatic experiences.

Based on the background above,This study aims to describe; 1) The role of peer support groups to restore the resilience of PLWHA. 2) the impact of social support on restore resilience of PLHAs.

\section{METHODOLOGY}

This study uses a qualitative approach. Data collection techniques using indepth interviews, observation and focus group discussions. The study subjects were members of PSG and PLWHA.Data analysis is done by applying analytical methods that are commonly used in field research. The collected data was analyzed using an analysis strategy that is an interactive model by Miles, Huberman, and Saldana [12] This model looks at analysis as three concurrent activities: (1) condensation of data, (2) display data, and (3) conclusion drawing/verification. In this way, explore each of these components more deeply when the researcher reads the data.

\section{LITERATUR RIVIEW}

\section{Resilience}

The concept of resilience emerged since 1980, in an effort to understand individuals in response to stress and adversity. The basic conceptualisation of resilience as adaptation despite adversity is broadly evident, however resilience is contextual in many ways. Therefore, resilience is best understood as multidimensional and variable across time and circumstance. Acording Rutter [13] Resilience is understood, therefore, not only as a characteristic of the individual, but also as part of the existing dynamic interaction between individual characteristics and their social context. Smith and Hayslip [14] suggest that intrapersonal, interpersonal, and 
Page 119-136. ISBN: 978-602-6 988-75-1

Web Jurnal Online: jurnal.unmuhjember.ac.id

By: Rinikso Kartono

The Role Of Peer Support Group To Restore The Ability

Of Resilience Of People With Hiv / Aids (Plwha)

environmental (including community) resources can contribute to resilience. While, Werner [15] noted three general usages of resiliences : good developmental outcomes despite high risk status; sustained competence under stress; and recovery from trauma.

Hardy SE, at all [16]conceptualizes resilience as patterns of adaptation in the context of situations of risk or adversity: exposure to significant risk, and evidence of positive adaptation to threats to development. Positive adaptation refers to successful development despite the risks: ability to deal with stress, including the capacity to minimise the effects of the stressful event; capacity for a rapid recovery from a trauma; and, in the long term, ability to contain negative responses and capacity to promote positive consequences and behaviours that enable the individual to overcome adversity. According to VanBreda [17], resilience means the skills, abilities, knowledge, and insight that accumulate over time as people struggle to surmount adversity and meet challenges. While, Smith \& Hayslip, [14] defines resilience as a pattern of positive adaptation in the context of past or present adversity or risk.

According Masten et al. [18] resilience is 'the process of, capacity for, or outcome of successful adaptation despite challenging or threatening circumstances'. Tusaie and Dyer [19]recognizes that resilience as a dynamic process a personal negotiation through life that fluctuates across time, life stage. The process of resilience is complex and it involves interaction between adversity and an individual's internal and external protective factors as well developed competencies that allow one to overcome adversity [20]

Resilience is a comprehensive process that involves understanding personality traits, external factor such as family, friends, support group as well as outcomes such as increased self-esteem or social competence. Resilience is a process that is affected by protective and vulnerability factors [21]. The resilience process is also related to the dimensions of a personal psychology with a supportive mindset and a way of living that supports the individual's values and the social environment, family, physical environment [22; 23].

An individual's level of resilience is seen as being based on protective factors (internal and external) which can alter a person's response to given environmental circumstances [24]. Smith and Hayslip [25] suggest that individual resilience at one point in time may be much less (or more) resilient at a different time as adversity can accumulate. A sense of bouncing back from an adverse event, such as an HIV diagnosis, could be hampered by intrapersonal, interpersonal, and environmental contexts, including experiences of discrimination, victimization, internalized stigma, and depression.

A person's resilience ability is influenced by intrinsic factors and extrinsic factors. A number of intrinsic factors such as temperament and sense of humour are known to be associated with levels of vulnerability or resilience, three key features that have been identified are: secure base, self esteem and self effi cacy. While, the protective factors are ; at least one secure attachment relationship, access to wider supports such as extended family and friends and positive nursery, school and or community experiences.[26] 
Page 119-136. ISBN: 978-602-6 988-75-1

Web Jurnal Online: jurnal.unmuhjember.ac.id

By: Rinikso Kartono

The Role Of Peer Support Group To Restore The Ability

Of Resilience Of People With Hiv / Aids (Plwha)

Positive results related to resilience are alleviating the negative effects of stress, increasing adaptation, and developing effective coping skills to deal with change and difficulties. Resilience is therefore defined as the ability of individuals to choose to recover from sad and challenging life events, by increasing knowledge to be adaptive and addressing adverse situations in the future [27]. Murphey [28] discribes the characteristics of humans who have high resilience are tend to be easygoing and easy to socialize, have good thinking skills (traditionally called intelligence, which also includes social skills and the ability to judge something), have people around who support, have one or more talent or excess, confident in themselves and believe in their ability to make decisions and have spirituality or religiosity.

Herrman, at all [29] say that sources of resilience include the following: first, personality factors, including personality characteristics, self-efficacy, self-esteem, internal locus of control, optimism, intellectual capacity, positive self-concept, demographic factors (age, gender, ethnicity), hope, resilience, emotional regulation, and so on. Second, biological factors. The initial environment will affect the development and structure of brain function and the neurobiological system. Third, environmental factors such as family and peer social support, family stability, safe and secure relationships with parents. Furthermore, a broader environment, namely a community system such as a school environment, social service, opportunities to carry out sports and arts activities, spirituality and religion as well as little experience related to violence.

Rutter, M. [30] identified three characteristics of a person who showed resilience; 1) A sense of self-esteem and self-confidence, 2) A sense of self-efficacy (belief in their capacity to make a difference) and 3) A repertoire of social problem-solving approaches. Similarly, Lerner, R., Fisher, C. and Weinberg, R. [31] summarized by the "5 C's" or five clusters of individual resilience attributes:

a. Competence (intellectual ability, social and behavioral skills)

b. Connection (positive bonds with people and institutions)

c. Character (integrity and moral centeredness)

d. Confidence (positive self-regard, sense of self-efficacy, courage)

e. Caring/Compassion (human values, empathy, a sense of social justice)

The five core characteristics of one"s resilience core, considered to be the most important part of one's inner being [32]. First, purpose is considered the foundation of one's resilience core and is associated with a meaningful life. Without purpose in one's life, there is lack of ambition in which progress can be derailed. Second, perseverance, as the ability to push forward regardless of current situations or circumstances. Third, equanimity, as balance and harmony regardless of good or bad circumstances. Equanimity is a trait that describes individuals who are optimistic and open to possibilities of whatever life brings regardless of their current situations. Fourth selfreliance. Self-reliant individuals learn from their experiences of adversity and challenges and in the process develop problem learning skills from these experiences. The more the individual encounter challenges, their skills of self-reliance are refined, and strengthen and self-confidence strengthened Finally, existential aloneness. This characteristic trait addresses the fact that resilient individuals leam to live with themselves and thus become 
Page 119-136. ISBN: 978-602-6 988-75-1

Web Jurnal Online: jurnal.unmuhjember.ac.id

By: Rinikso Kartono

The Role Of Peer Support Group To Restore The Ability

Of Resilience Of People With Hiv / Aids (Plwha)

comfortable with whom they are and what they have become. Therefore, one who possesses existential aloneness is satisfied and content with his or her life regardless of past failures and disappointments.

\section{Resilience in PLWHA Contex}

Resilience AIDS is seen as a "long wave event" taking years for the epidemic to spread through the society and generations for the full impact to be felt. Vulnerability in the context of AIDS has three phases: Upstream (relating to risk of an individual becoming exposed to, and infected with HIV), Midstream (individual risk of developing opportunistic infections after HIV Resilient persons living with HIV/AIDS have number of ways, including level of knowledge of their illness, self-responsibility, persistence [33], an increased quality of life, low levels of psychological distress, positive beliefs, and the ability to relinquish control over the uncertainty of life with HIV infection [34]. In addition, some evidence suggests that resilient persons with HIV infection have the ability to spiritually transcend their illness [35]

In the context of person living with HIV / AIDS, the notion of resilience is more appropriate with the statement Ferreira and Ebersöhn [36] that resilient people are inclined to be more resourceful in their problem solving and exhibit greater personal insights into their own strengths than less resilient individuals. Adegoke [37] defines resilience as adolescent girls' process of bouncing back from hardships such as the trauma and stresses associated with HIV infection and it prevails among these circumstances by reverting to the original productive functioning or a higher level of performance than before. According Olsson CA, at all, [38], resilience to mean the ability of patients on anti retroviral treatment (ART) to solve risk posed by psychological, social and economic barriers to sustain adherence to HIV treatment.

\section{Social Support And Resilience Of PLWHA}

Social support is related to the well-being of someone who is HIV and acts as a buffer against stress and and depression [39;40]. According Khan, Hena, [41] that social support may play a small but potentially important role in helping HIV-positive people to become more resilient and adhere to the complicated schedules for taking their drug and for making better immunity to fight from infections and control the virus that causes AIDS. Social support and resilience are deeply interconnected to each other and they also have great impact on either one. It is possible that due to the greater social support the resilience power increases. On the other hand if someone has better resilience power than before his social support may also increase. The results of data analysis through analysis concluded that there was a significant correlation between social support and resilience. $[42 ; 7]$

As Herrman, at all [28] said above, one of the factors that can increase resilience is peer social support. According to Carter, [43] support groups help bring together the needs of people living with HIV / AIDS (PLWHA), with those who love one another and caregivers. The caregivers include a variety of loving people, from PLHIV themselves, 
Proceeding ICOGISS 2019

Page 119-136. ISBN: 978-602-6 988-75-1

Web Jurnal Online: jurnal.unmuhjember.ac.id

By: Rinikso Kartono

The Role Of Peer Support Group To Restore The Ability

Of Resilience Of People With Hiv / Aids (Plwha)

friends, health care professionals, and facilitators from support groups. These support groups can function:

a. Providing a relaxed and informal place for PLWHA, to share experiences and build new friendships.

b. Provide opportunities for couples (at least one of whom is HIV-positive) to discuss relationships, law, health, and other issues related to them.

c. Provide special groups of specific people - a peer support group to discuss their HIV / AIDS experiences in their lives.

Support groups are especially important for people who are HIV positive. So many emotional problems faced by people who have been diagnosed with HIV positive. They face changes in social support and financial situations, they can become afraid, confused, and worried. When other people reject them and treat them inappropriately, they can become depressed, angry, and isolated.

Furthermore, according to Carter, [43] in the support group, PLWHA met other people who had the same experience, they learned that they were not alone and could build a new life. PLWHA can also benefit from special support groups to deal with their problems, which involve feelings of fear of infectious diseases and infections, sadness, changes in social conditions, health, and obsessive thoughts. Support groups in PLWHA are often the main source of love and acceptance. Usually people get acceptance, support, support, and intimacy from their birth families, friendship groups, and or religious groups.

There are four common types of social support [41];

a. Emotional support: It is the offering of empathy, concern, affection, love, trust, acceptance, intimacy, encouragement, or caring. It is the way to tell a particular person that someone is standing by him in his need. Through this support an individual feels that he is also a part and parcel of society and not ignored. It is also sometimes called esteem support or appraisal support.

b. Tangible support: In this materialistic world economical support matters most for the person who is suffering from mental stress, health problem as well as economical problem. No matter how crucial your problem is. Nobody is going to listening you if you are in want of money. The provision of financial assistance, material goods, or services is known as tangible support or instrumental support. This form of social support encompasses the concrete, direct ways people assist others.

c. Informational support: It is the provision of advice, guidance, suggestions, or useful information to someone. This type of information has the potential to help others problem-solve.

d. Companionship support: It is the type of support that gives someone a sense of social belonging. This can be seen as the presence of companions to engage in shared social activities. 
Proceeding ICOGISS 2019

Page 119-136. ISBN: 978-602-6 988-75-1

Web Jurnal Online: jurnal.unmuhjember.ac.id

By: Rinikso Kartono

The Role Of Peer Support Group To Restore The Ability

Of Resilience Of People With Hiv / Aids (Plwha)

\section{RESULT}

\section{The role of peer support group (PSG) to improve the resilience of PLWHAs.}

The role of PSG is pivotal to increase PLWHA's resilience in dealing with problems and life's responsibilities. This is because most people who are infected with HIV / AIDS will experience a resilience degradation, so they are easy to get frustrated and stressed in dealing with their illness, susceptible to disease, powerlessness, and self-exclusion. The results of the study found four roles of PSG that could be applied to improve PLWH resilience consequently PLWHA could undergotheir normal life, namely;

a. Provider Temporary Shelter

Almost of all PSGs provide the temporary shelter for PLWHA who has been diagnosed a positive HIV/AIDS by doctor. They usually get shock and stress because they are afraid of being ignored by their family, so the temporary shelter is needed. The purpose of the temporary shelter is to provide the comfortable and literacy place for PLWHAs to deal with problems. As it is stated by PSG BC:

"Shelter is really important to everyone who has infected by HIV / AIDS. It is because they experience the change of their life, so they get shocked and stressed. Also, they do not want to go home and they are rejected by their family.Consequently, this shelter may be a comfortable place for them, because they can meet with other PLWHAs, support each other, and share their knowledge. In the shelter, PLWHAs are taught how to live and to deal with problems so that they will not get more shock and stress".

b. Companion and Counselor

PLWHAs usually need an assistance (a companion) and counseling from PSG for a certain time. An assistance (a companion) and counseling are needed for someone who will do a voluntary counseling test (VCT) until the doctor declares that he/she has a positive HIV / AIDS. This prepares PLWHAs psychology to avoid stress, to make them to not feel alone, and to prevent suicidal desires. Furthermore, if he/she is diagnosed by a positive HIV / AIDS, an assistance and counseling will be needed for anti-retroviral therapy (ART), accordingly they will know the benefits of ART for their health and they will not stop their therapy. Other assistance/companion and counseling are when they get the stigma and discrimination from family, friends, neighbors and from school. This is stated by Mr. BB:

"Thecompanion and counseling are needed by PLWHAs to avoid stress, to make them not feel alone, and to keep them away from the suicidal desires when they are diagnosed a positive HIV / AIDS by doctors, so they can deal with it. We provide them a companion and counseling when they are doing ART. Consequently, they know the benefits of it for their health and they will continue their therapy. Also, if they are stigmatized and discriminatedby their family or others, we will accompany them,sir.We will absolutely be their side until they are able and have the resilience to face problems".

c. Educator and Trainer

The role of PSG is also often seen as an educator and trainer. As an educator, PSG teaches various knowledge needed by PLWHAs. This is because 
Proceeding ICOGISS 2019

Page 119-136. ISBN: 978-602-6 988-75-1

Web Jurnal Online: jurnal.unmuhjember.ac.id

By: Rinikso Kartono

The Role Of Peer Support Group To Restore The Ability

Of Resilience Of People With Hiv / Aids (Plwha)

many people who are infected with HIV / AIDS do not have knowledge about HIV / AIDS, they do not know how to treat it, how to access health services, and how to live properly as PLWHAs. Moreover, PSG also conducted entrepreneurships trainings so that the PLWHAs could be independent and empowered persons. As it is stated by Mrs. TI:

"The PLWHAs biggest problem is they lack of literacy, especially about HIV / AIDS, the treatment and many more. Our presence in PSG is needed to educate them about the basic knowledge of HIV / AIDS, its treatment, and how to access the health services. Also, they need entrepreneurship training so they can be independent persons. In fact, many of them do not work because they are fired or they resign from his job. Thus, they are to be healthy and be able to run their life independently.

d. Advocate

PSG can be an advocate when PLWHA is stigmatized and discriminated to get access to social services. It is done to make PLWHA gets their rights as citizens such as health, education, and to be treated humanely. There are various cases that struck PLWHAs which are successfully advocated, as it is stated by Mrs. TI:

"The cases of stigma and discrimination are often experienced by PLWHA, sir. I once advocated for an HIV positive child who was refused from the school. Then, I was facing the school principal and the head of the local government education affairs. I explained that refusing children living with HIV is against the law. I also explained that HIV cannot transmit simply because of being friend with PLWHA and touching their body. Finally, they accepted the child and allowed him/her to go back to school."

Advocating PLWHAs that get stigma and discrimination is also carried out by PSG members named Mr. MX in the case of PLWHA which does not have access to health.Mr MX said:

"At that time there were PLWHAs who reported to me if he was rejected by village head for a relief letter (SKTM). The relief letter is important to get health service assistance for free. Then, I went to the village head, and I explained that the relief letter (SKTM) was the right for the poor to get free services. If the letter was not given to the poor, it meant that the village head violated the law. After I explained them all briefly, the village head finally gave a relief letter (SKTM) to the PLWHA."

\section{The Impact of Social Support on Restoring the Resilience of PLWHAs}

a. PLWHA can adapt to HIV / AIDS which infects it

Being infected by HIV / AIDS, is a traumatic event that can reduce one's physical, mental and social relationships. Most of PLWHA, experienced stress, fear, and they did not accept their status as PLWHA. Also,they were unable to adapt to the impact 
Page 119-136. ISBN: 978-602-6 988-75-1

Web Jurnal Online: jurnal.unmuhjember.ac.id By: Rinikso Kartono

The Role Of Peer Support Group To Restore The Ability Of Resilience Of People With Hiv / Aids (Plwha)

of HIV / AIDS which was so complex. So, they are frustrated and they attempt toend their life. Yet, the suicidal desire gradually disappeared after a peer support group (PSG) member accompanied and support them. Additionally, PSG members usually explain that living with HIV / AIDS is not the end of life. The important one is how PLWHA changed their mindset about HIV / AIDS and changed their way of life. The actions which are done by PSG gradually made PLWHAs rise and they are more optimistic to stay healthy and be able to adapt to the disease. It is like Mrs. Yn said:

"I had a chance to end my life after being told by a doctor that I had HIV / AIDS. It has been a year after a friend from PSG came to my home and gave me an explanation that being infected by HIV / AIDS was not the end of life.Afterwards, I did not want to kill myself anymore. The PSG friend said that he was also PLWHA and he looked healthy, even though he said that he had HIV / AIDS for a long time. As the time went by, I was able to accept this disease and I wanted to stay alive. I consider that I am okay with this disease, I am healthy and comfortable even as PLWHA until now ... ha ... ha ... ha ... "

The role of PSG can also increase the confidence of someone who is infected by HIV / AIDS. This is because if a PLWHA is inferior to his status, he will isolate himself and does not go to work because he is afraid that his status will be known by others. Mr. HS is one of the successful PLWHA after being trained and counseled by PSG. He became a confident person, he slowly began to accept his illness and dared to leave the house, worked in a restaurant and dared toshow himself in public with open status as a speaker. This is as Mr, Hs stated:

"Now, I feel comfortable sir. I used to be at home and I was afraid of going out. I did not want to let others know that I am PLWHA. If they know, I will be kicked out from here. Also, I resigned from my work because I was afraid if they knew my status and fired me. Fortunately, when I went to the doctor, I was given the training by PSG Spiritia from Jakarta. After being trained, I just found out that many people who had the same fate with me still did their activities outside the home such as working. They could enjoy their life even though they had HIV / AIDS. So, I decided to work again. Finally, I also established PSG UNX and I was braver to accept an invitation to open status as a speaker at several HIV / AIDS forums. I do not want other people experienced the same thing like I had before."

People who are infected with HIV / AIDS will also not feel comfortable, and they have full of fear, so that they experience stress and depression. This was the target of PSG's intervention to help reduce the stress and depression. This is as stated by Mr. BB:

"We are from PSG, know that people infected with HIV / AIDS always experience stress and depression. If we do not help them to reduce their stress and depression, it will disrupt their health and their life will become abnormal. So, we do counseling, hold meetings with PLWHAs and sometimes we invite them to have a vacation to somewhere in order to refresh their mind. We also accompany them until their lives feel comfortable." 
Proceeding ICOGISS 2019

Page 119-136. ISBN: 978-602-6 988-75-1

Web Jurnal Online: jurnal.unmuhjember.ac.id

By: Rinikso Kartono

The Role Of Peer Support Group To Restore The Ability

Of Resilience Of People With Hiv / Aids (Plwha)

What were done by PSG members, the researcher confirmed one of the PLWHA who was his client, named WA. WA told about his stress and depression that he experienced until he recovered after seeing a $\mathrm{BB}$ at the hospital. He was then invited to the shelter to meet others PLWHA members. As stated by WA:

“...I used to be stressed, sir. I got depression, and I even banging my head against the wall. Hahaha. It was terrible. Then, after meeting Mr. BB at the hospital, I was invited to the shelter to and met with other PLWHA members. I was very happy meeting them, since that time, I often went to the shelter. I was counseled and motivated, there. I once invited to go to the beach for holiday. After that, I have never been stressed or even depressed. I accept HIV / AIDS wholeheartedly, I am comfortable and I can live with this disease ... without fear, without stress"

Another PLWHA member named Mrs. AV was also experiencing about the process of changing mindset and adaptation to the disease. Before getting information from KDS, she always stigmatizes herself bad, weak and useless. These self-stigmas make her powerlessness. However, after gaining an education from KDS PH, she was confident and empowered in her own life. Based on Mrs. AV statement, as follow:

"I was not like this, sir. I used to consider myself ugly, weak, useless, would die quickly and if I die, my body is ugly, black and thin. I gave up ... But after being educated and motivated by KDS friends, I tried to get up and be able to see myself positively. Oh, it turns out that PLWHA's appearance can be the same as someone else's. Now, I love my body and life as they are. I do not want to give up just because of HIV / AIDS. I have to stay beautiful, healthy, long life, can work and do well for others. How can other people see me, if I see myself negatively."

b. Improvement in the quality of PLWHA's health

Living healthy and feeling healthy is one of the keys to increase the resilience of PLWHA. In fact, many people do not recognize that they are infected with HIV / AIDS even their lives are at high risk and do not know how to figure it out. The existence of PSG often goes to high-risk groups to provide awareness and knowledge of the importance of conducting voluntary tests or so-called voluntary counseling tests (VCT). Mr.Hq is PLWHA who caused by injection drug use (IDU) alternately with his friends. He was lucky to know HIV from an early age, so he was not infected by AIDS, with CD 4 in the number 800 . This was because of the advice and explanation given by Mr. YD from PSG. Until now, he is healthy because he still maintains health as suggested by Mr. YD. As stated in the following statement;

"I have never been sick, even though I am HIV-positive. I knew that I was infected with HIV from an early age. So, I did not get infected by an IO (infection opportunity). That was because I met Mr. YD when I was IDU, then I was advised to take a VCT and transfer to the hospital. It turned out that my VCT results were HIV-positive. My CD 4 is 800 . So I have not got OI and I take ARV. I often consult Mr. YD, to maintain health, for example, I have to be diligent in 
Proceeding ICOGISS 2019

Page 119-136. ISBN: 978-602-6 988-75-1

Web Jurnal Online: jurnal.unmuhjember.ac.id

By: Rinikso Kartono

The Role Of Peer Support Group To Restore The Ability

Of Resilience Of People With Hiv / Aids (Plwha)

exercising, having enough rest, not to be stressed. I always follow his advice, because he was also PLWHA just like me. "

Another different story comes from Mrs. AF who had been hospitalized because she was infected by AIDS. When she was in the hospital, she met Mr.YD, member of PSG. Since that time until he was as healthy as now, Mr. YD and his friends from PSG often home visits and invited to the shelter to be educated about healthy living despite being infected with HIV/AIDS. Mrs. AF said:

"After recovering, I received a lot of knowledge from PSG friends, such as, knowledge about HIV / AIDS, drugs and side effects, how to access health services, understand about HIV / AIDS and self-care. Sometimes, Mr. YD did home visits or I went to the shelter to be educated. God bless because I still healthy until now, my CD 4 is 900, and I can go to work again."

c. Restore Social Roles.

People who are infected with HIV / AIDS will change their social life, such as being self-disclosed and even isolating themselves from their social environment. However, because of PSG's efforts, the condition can be restored as before, daring to open its status even in a limited social environment, and daring to face the risk of being stigmatized and discriminated. This is as stated by Mrs. YN;

“...after being infected, I became a closed person. In fact, I always shut myself up at home. After being counseled and accompanied by Mr. BB, a PSG member, I began to realize the importance of being open especially to my family, and not afraid to be discriminated. It was because I obtained information from PSG, I can explain to my family that I was infected with HIV / AIDS. I even dared to leave the house to work. Once someone knew about my status, but I was not afraid that they would stigmatize and discriminate. I am ready to explain my illness. "

PSG's role also makes PLWHA become confident to get married and can even plan to have children without transmitting the disease. Mr. Pr is one of the PLWHA who has an HIV-negative child. This is because of the guidance and counseling from PSG, and then joined the prevention program of mother to child transmission (PMTCT), with ARV prophylaxis, and giving the right baby food. Mr. Pr, said;

"When I was about to get married, I talked to my girlfriend about the agreement not to have children for fear of contracting HIV. But after marriage, we met with KDS friends, and they say that it was okay to have children. They said that, even though their parents were infected with HIV / AIDS, it was not necessarily transmitted to their babies as long as they joined the PMVCT program. I was explained about PMVCT, and made me eager to have children. Then I was taken to the doctor for a consultation program to have children. Yes, I now have a HIVnegative child. I have a happy life, sir..."

d. PLWHA becomes more pro-social and religious

The main role of PSG is providing counseling to change the behavior of PLWHAs to be pro-social and more religious. They have concern for others, 
Page 119-136. ISBN: 978-602-6 988-75-1

Web Jurnal Online: jurnal.unmuhjember.ac.id By: Rinikso Kartono

The Role Of Peer Support Group To Restore The Ability Of Resilience Of People With Hiv / Aids (Plwha)

especially to PLWHAs who are newly infected. Besides that, thanks to PSG's guidance, their lives are more religiously by going to the mosque or to the church. As stated by Mr. G:

"I used to be selfish, sir. I do not care about other people. I am Muslim but I have never been to a mosque. Anyway, I have a bad life; I like to drink, IDU, free sex. Then, after being infected with HIV / AIDS and always being guided by PSG friends, I changed my life. I also see how good the PLWHAs at PSG are, they help others, and they are diligent in worshiping. I became embarrassed and finally imitated them. Now I often go to the mosque and also accompany the newly infected PLWHA."

\section{DISCUSSION}

The first purpose of this study was to discribes the role of peer support groups to restore the resilience of PLWHA. The results of this study found the data that the role of peer support groups to restore the resilience of PLWHA are; provider temporary shelter, companion and counselor, educator and trainer, advocad.

The reason PSG provided temporary shelter, because PLWHA did not want to go home, felt alone and they were rejected by their family, and often experienced shock and stress after positive HIV / AIDS. Therefore by providing shelter can be a comfortable place, feel not alone, they can meet with other PLWHAs, support each other, love each other and share their knowledge. In the shelter, PLWHAs are taught how to live and to deal with problems so that they will not get more shock and stress.

This finding confirms Carter's [43] statement that support support groups help bring together the needs of people living with HIV / AIDS (PLWHA), with those who love one another and caregivers. The caregivers include a variety of loving people, from PLHIV themselves, friends, health care professionals, and facilitators from support groups. Peranan PSG yang ditemukan dalam studi ini juga bisa dianggap sebagai dukungan emosional. According Khan, Hena [41] emosional support is the offering of empathy, concern, affection, love, trust, acceptance, intimacy, encouragement, or caring. It is the way to tell a particular person that someone is standing by him in his need. Through this support an individual feels that he is also a part of society and not ignored. It is also sometimes called esteem support or appraisal support.

As explained above, PLWHA often experiences stress, wants to commit suicide, is afraid of facing illness, death, stigma and discrimination. Therefore the role of the PSG as a companion and counselor is needed to help reduce stress, reduce feelings of fear and direct PLWHA to think and behave positively. According Khan, Hena [41]Companionship support is the type of support that gives someone a sense of social belonging. This can be seen as the presence of companions to engage in shared social activities. This also proves that social support is related to the wellbeing of someone who is HIV and acts as a buffer against stress and and depression [39;40] 
Proceeding ICOGISS 2019

Page 119-136. ISBN: 978-602-6 988-75-1

Web Jurnal Online: jurnal.unmuhjember.ac.id

By: Rinikso Kartono

The Role Of Peer Support Group To Restore The Ability

Of Resilience Of People With Hiv / Aids (Plwha)

As an educator, PSG teaches various knowledge needed by PLWHAs. This is because many people who are infected with HIV / AIDS do not have knowledge about HIV / AIDS, they do not know how to treat it, how to access health services, and how to live properly as PLWHAs. Moreover, PSG also conducted entrepreneurships trainings so that the PLWHAs could be independent and empowered persons

PSG can be an advocate when PLWHA is stigmatized and discriminated to get access to social services. It is done to make PLWHA gets their rights as citizens such as health, education, and to be treated humanely. Through advocacy carried out by PSG, PLWHA can access social services so that they can improve their knowledge and health and obtain humane treatment. Finally PLWHA can be empowered.

The second purpose of this study was to discribe the impact of social support on restoring the resilience of PLHAs. From the studies that have been conducted, several implications of social support for the resilience of PLHAs have been found. One impact is the change in mindset about HIV / AIDS which was previously considered a frightening and stressful disease, isolating themselves and wanting to commit suicide, but now HIV / AIDS is considered an ordinary disease. They can accept and adapt to HIV / AIDS and more confidence. They are not easy to experience stress, on the contrary able to manage stress positively and be more hardiness. This implies that PLWHA resilient has number of ways, including level of knowledge of their illness, self-responsibility, persistence [33], an increased quality of life, low levels of psychological distress, positive beliefs, and the ability to relinquish control over the uncertainty of life with HIV infection [34]. Besides that it also proves that PLWHA has resilience capabilities, because it has been able to adapt positively. Positive adaptation refers to successful development despite the risks: ability to deal with stress, including the capacity to minimise the effects of the stressful event; capacity for a rapid recovery from a trauma; and, in the long term, ability to contain negative responses and capacity to promote positive consequences and behaviours that enable the individual to overcome adversity [16]. Positive results related to resilience are alleviating the negative effects of stress, increasing adaptation, and developing effective coping skills to deal with change and difficulties. Resilience is therefore defined as the ability of individuals to choose to recover from sad and challenging life events, by increasing knowledge to be adaptive and addressing adverse situations in the future [27]

Although not a doctor, the role of PSG's social support is very important to help doctors improve the quality of PLWHA's health through education. This is because not all PLWHA get information from doctors or from health services. The PSG experience is a useful source of health information for PLWHA. Many PLWHA acknowledge that with the education provided by PSG to know how to live healthy despite being infected with HIV / AIDS, know about the treatment, and know how to access the health services. Increasing the quality of PLWHA's health can be proven by increasing CD4, weakening and decreasing HIV virus, loss of infection opportunities, they can work and they don't infect their babies. This means that 
Page 119-136. ISBN: 978-602-6 988-75-1

Web Jurnal Online: jurnal.unmuhjember.ac.id By: Rinikso Kartono

The Role Of Peer Support Group To Restore The Ability Of Resilience Of People With Hiv / Aids (Plwha)

PLWHA has had resilience as formulated by Van Brenda [17] as skills, abilities, knowledge, and insight that accumulate over time as people struggle to surmount adversity and meet challenges.

Another impact of PSG's social support for improving PLWHA's resilience capabilities is that they can return to carrying out their social roles again. If previously their lives were more closed and isolated, experienced dependency, and could not carry out their life's tasks to be restored. Even some PLWHA dare to open status as speakers about HIV / AIDS in public. They can return to live with family and society, go back to work, get married and have children.

They also participate socially as taught by PSG, so that their lives are more meaningful. Wagnild, [32] calls life meaningful as the foundation of one's resilience core. A more meaningful life is expressed with the participation of HIV / AIDS prevention campaigns and caring for fellow PLWHA. They become brave in voicing their rights when accessing social services and fighting stigma and discrimination by actively educating families, schools and communities. This also shows the characteristic that PLWHA has resilience. This refers to the opinion of Rutter, M. [30] which states that there are three characteristics of a person who showed resilience; 1) A sense of self-esteem and self-confidence, 2) A sense of self-efficacy (belief in their capacity to make a difference) and 3) A repertoire of social problemsolving approaches. Then Lerner, R., Fisher, C. and Weinberg, R. [31] identify individual resilience attributes including: 1) Competence (intellectual ability, social and behavioral skills); 2) Connection (positive bonds with people and institutions); 3) Character (integrity and moral centeredness); 4) Confidence (positive self-regard, sense of self-efficacy, courage); 5) Caring / Compassion (human values, empathy, a sense of social justice).

Finally the life of PLWHA is more religious. They actively came to the mosque, came to the church to pray. They ask God to be forgiven of his sins, avoid sins and prepare himself if God takes away his life. This is an indicator that the resilient persons with HIV infection have the ability to spiritually transcend their illness [35]

\section{CONCLUSION}

From the discussion above, it can be concluded that; 1) Therole of peer support groups to restore the resilience of PLWHA are; a) Provider temporary shelter; 2) Companiopn and counselor ; c) Educator and trainer, d) Advocad. (2) The roles of peer support group to improve the resilience of PLWHA consists of; a) PLWHA can adapt to HIV / AIDS which infects it, optimistic, hopefull, without experiencing stress; b) improvement in the quality of PLWHA's health; c) increasing social role of plwha; d) PLWHA becomes more pro-social and religious 
Proceeding ICOGISS 2019

Page 119-136. ISBN: 978-602-6 988-75-1

Web Jurnal Online: jurnal.unmuhjember.ac.id By: Rinikso Kartono

The Role Of Peer Support Group To Restore The Ability Of Resilience Of People With Hiv / Aids (Plwha)

\section{REFERENCES}

Ministry of Health of the Republic of Indonesia (http://spiritia.or.id/Stats/Statistik.php)

Yu, X., Lau, J. T., Mak, W. W., Cheng, Y., Lv, Y., \& Zhang, J. (2014). A pilot theorybased intervention to improve resilience, psychosocial well-being, and quality of life among people living with HIV in rural China. Journal of Sex \& Marital Therapy, 40, 1-16. doi:10.1080/0092623X.2012.668512

Lyon ME, Garvie PA, Kao E, Briggs L, He J, Malow R, McCarter R. (2010), Spirituality in HIV-infected Adolescents and Their Families: FAmily CEntered (FACE) Advance Care Planning and Medication Adherence. Journal of Adolescent Health. 2011;48(6):633-636. doi: 10.1016/j.jadohealth.2010.09.006.

De Santis, J. (2008). Exploring the concepts of vulnerability and resilience in the context of HIV infection. Research and Theory for Nursing Practice, 22, 273-287.

Kartono, Rinikso, (20110, Ketidakberdayaan Orang Dengan HIV/AIDS di Kota Malang, Sosiokonsepsia, Vol 16 No. 03, pp. 295-313.2011.

Radha R Chada, Venkat Pulla, Bharath Bhushan Mamidi, Azlinda Azman , (2014), Fighting HIV/AIDS and Resilience Perspectives, International Journal of Social Work and Human Services Practice, Horizon Research Publishing, Vol.2. No.3 Jun, 2014, pp. 89-95

Alaiya Choiril Mufidah,( 2017), Hubungan Antara Dukungan Sosial dan Resiliensi dengan Locus Of Control sebagai Moderator Pada Mahasiswa Bidikmisi, Psikodimensia, Vol. 16; No. 2,

Fang, X., Vincent, W., Calabrese, S. K., Heckman, T. G., Sikkema, K. J., Humphries, D. L., \& Hansen, N. B. (2015), Resilience, stress and life quality in older adults living with HIV/AIDS. Aging and Mental Health. doi:10.1080/13607863.2014.1003287

Emlet, C.A., Tozay, S., \& Raveis, V. H. (2010). "I"m not going to die from AIDS" Resilience in aging with HIV disease. The Gerontologist, 51: 101-111

Kartono, Rinikso,(2013] Dukungan Sosial Berbasis Kelompok Dukungan Sebaya Dalam Mengatasi Ketidakberdayaan Orang Dengan HIV/AIDS, Sosiokonsepsia, Vol 18 No. 01, pp. 89-109.2013.

Cluver L, Orkin M. (2009), Cumulative risk and AIDS-orphanhood: Interactions of stigma, bullying and poverty on child mental health in South Africa. Social Science \& Medicine. 2009;69(8):1186-1193. doi: 10.1016/j.socscimed.2009.07.033.

Miles, Matthew B. \& Huberman A.M., Johnny Saldana, (2014), Qualitative Data Analysis: An Expanded Sourcebook (edition 3), Thousand Oaks, CA: SAGE.

[ 13 ] Rutter, M. (1985) Resilience in the face of adversity: Protective factors and resistance to psychiatric disorder. British Journal of Psychiatry, 147: 598-611

Smith, G. C., \& Hayslip Jr., B. (Eds.). (2012). Resilience in adulthood and later life: What does it mean and where are we heading? Annual review of gerontology and geriatrics. Emerging perspectives on resilience in adulthood and later life (Vol. 22, pp. 3-28). New York: Springer. 
Proceeding ICOGISS 2019

Page 119-136. ISBN: 978-602-6 988-75-1

Web Jurnal Online: jurnal.unmuhjember.ac.id

By: Rinikso Kartono

The Role Of Peer Support Group To Restore The Ability

Of Resilience Of People With Hiv / Aids (Plwha)

Werner, E. E. (1995). Resilience in development. Current Directions in Psychological Science, 3, 81-85.

Hardy SE, Contato J, Gill TM. (2004), Resiliencfe of Community-Dwelling Older Persons. J Am Geriatr Soc 2004; 52(2):257-262

Van Breda, A. (2001). Resilience theory: A literature review. Pretoria, South Africa: South African Military Health Service. Retrieved from http://www.vanbreda.org/adrian/resilience.htm

Masten, A. S., K. M. Best, and N. Garmezy. (1990). Resilience and development: Contributions from the study of children who overcome adversity. Development and Psychopathology 2: 425-444.

Tusaie, K. And Dyer, J. (2004) Resilience: a historical review of the construct. Holistic Nursing Practice. Vol 18, No 1. pp3-8.

Hunter, A., \& Chandler, G. (1999). Adolescent Resilience. Journal of Nursing Scholarship, 31(3), 243-247. Retrieved from http://onlinelibrary.wiley.eom/doi/10.1 111 /j. 1547- 5069.1999.tb00488.x/pdf

Woodgate, R. L. (1999). Conceptual understanding of Resilience in the adolescent with cancer: Part 1. Joumalof Pediatric Oncology Nursing, 76(35), 35-43.

Windle, G. (2011). What is resilience? A review and concept analysis. Reviews in Clinical Gerontology, 21, 152-169. doi: 10.1017/S0959259810000420

McAllister, M., \& Mckinnon, J. (2009). The importance of teaching and learning resilience in the health disciplines: A critical review of the literature. Nurse Education Today, 29, 371- 379. doi: 10.1016/j .nedt.2008.10.011

Staudinger UM, Marsike M, Baltes PB. (1993), Resilience and levels of reserve capacity in later adulthood: Perspectives from life-span theory. Development and Psychology 1993; 5:541-566.

Gilligan, R. (1997). Beyond permanence? the importance of resilience in child placement practice and planning. Adoption and Fostering, 21(1), 12-20.

Keye, M. D., \& Pidgeon, A. M. (2013). An Investigation of the relationship between resilience, mindfulness, and self-Efficacy. Open Journal Of Social Sciences, 1(6), 1-4. doi: $10.4236 /$ jss.2013.16001

Murphey, D., Barry, M., \& Vaughn, B. (2013). Positive mental health: Resilience. Child Trends: Positive Mental Health Resilience, January(January), 1-6.

Herrman, H., Stewart, D. E., Diaz-Granados, N., Berger, E. L., Jackson, B., \& Yuen, T. (2011). What is resilience ? Can Jpsychiatry, 56(5), 258-265.

Rutter, M. (1985) Resilience in the face of adversity: Protective factors and resistance to psychiatric disorder. British Journal of Psychiatry, 147: 598-611

Lerner, R., Fisher, C. and Weinberg, R. (2000) Toward a science for and of the people: Promoting civil society through the application of developmental science. Child Development, 71 (1): 11-20.

Wagnild, G. (2010). Discovering your resilience core. Retrieved 04 25, 2013, from http://www.resiliencescale.com/papers/pdfs/Discovering_Your_Resilience_Core.p df 
Proceeding ICOGISS 2019

Page 119-136. ISBN: 978-602-6 988-75-1

Web Jurnal Online: jurnal.unmuhjember.ac.id

By: Rinikso Kartono

The Role Of Peer Support Group To Restore The Ability

Of Resilience Of People With Hiv / Aids (Plwha)

Bletzer, K. V. (2007). Identity and resilience among persons with HIV: A rural African American experience. Qualitative Health Research, 17, 162-175.

Farber, E. W., Schwartz, J. A. J., Schaper, P. E., Moonen, D. J., \& McDaniel, J. S. (2000). Resilience factors associated with adaptation to HIV disease. Psychosomatics, 41, 140-146.

Gosselink, C. A., \& Myllykangas, S. A. (2007). The leisure experiences of older U.S. women living with HIV/AIDS. Health Care for Women International, 28, 3-20.

Ferreira, R. \& Ebersöhn, L. (2012). Partnering for Resilience. Van Schaik Publishers.

Adegoke, Catherine Olayinka (2015), Key Factors In Enhancing The Resilience Of HIV Positive Adolescent Girls In Nigeria, Faculty of Education University Of Pretoria, South Africa

Olsson CA, Bond L, Burns JM, Vella-Brodrick DA, Sawyer SM, (2003) Adolescent resilience: A concept analysis. J Adolesc. 2003 Feb 28; 26(1):1-1. PMID: 12550818

Dugan, V.; Agalar, F.; \& Sagek, I. (2001). Surgeons' attitudes towards HIV/AIDS in Tl!lrkey. AIDS Care, 13(2), 243-251.

Leask, C., Bor, R., Elford, J., Miller, R., \& Johnson, M. (1997). Selective disclosure: a pilot investigation into changes in family relationships since HJV diagnosis. Journal of Family Therapy, 14 (1), 59--69.

Khan, Hena, (2015), Effect of Resilience and Social Support on Immune - Activation in HIV Positive, The International Journal of Indian Psychology | ISSN 2348-5396 Volume 2, Issue 2, Paper ID: B00335V2I22015

Mochammad Rizki Aziz IGAA Noviekayati (2016), Persona, Jurnal Psikologi Indonesia Januari 2016, Vol.5, No.01, hal62-70

Carter, Nancy A. (1993.) Support Groups: Places of Healing , http://gbgmumc.org/health/hivfocus/focus023.cfm 